\title{
Fundamentalismo e religião da política: uma possibilidade da política como religião
}

\author{
Fundamentalism and political religion: a possibility of policy as religion
}

Heiberle Hirsgberg Horácio*

\begin{abstract}
Resumo
Este artigo apresenta argumentos que procuram viabilizar o entendimento de que o conceito de religião política - bem como as experiências políticas autoritárias representadas por ele, como o nazismo e o stalinismo - pode ser pensado em articulação ao conceito de fundamentalismo. Ademais, este artigo também apresenta possibilidades para que o conceito de religião civil - que também pode ser classificado como religião pública - mesmo sendo muitas vezes associado às experiências políticas tidas como democráticas - como as dos Estados Unidos e da França - também possa ser pensado em articulação ao de fundamentalismo. Para tanto, este trabalho, realizando uma atividade de delimitação e problematização conceitual, definirá o conceito de religião política, diferenciando-o do conceito de religião civil, e de certa forma do de religião pública, em uma tentativa de demarcar um conceito, de religião política, que tem sido mobilizado, por vezes com certa imprecisão, por pesquisadores de diferentes áreas. Conquanto o objetivo deste artigo não seja de colocar empiricamente à prova os conceitos supracitados, ao delimitá-los, potencializando-os, busca-se contribuir para melhores rendimentos em experimentos analíticos futuros.
\end{abstract}

Palavras-chave: Fundamentalismo. Religião da política. Autoritarismo. Democracia.

\begin{abstract}
This article presents arguments that seek to facilitate the understanding that the concept of political religion - as well as the authoritarian political experiences represented by it, such as nazism and Stalinism - can be thought of in conjunction with the concept of fundamentalism. Furthermore, this article also presents possibilities for the concept of civil religion - which can also be classified as a Public Religion - even though it is often associated with political experiences considered democratic - such as those of the United States and France - can also be considered in conjunction with that of fundamentalism. Therefore, this paper, carrying out an activity of delimitation and conceptual problematization, will define the concept of political religion, differentiating it from the concept of civil religion, and in a certain way from that of public religion, in an attempt to demarcate a concept of public religion, which has been mobilized, sometimes with a certain imprecision, by researchers from different areas. Although the objective of this article is not to empirically test the aforementioned concepts, by delimiting them, enhancing them, we seek to contribute to better yields in future analytical experiments.
\end{abstract}

Keywords: Fundamentalism. Political religion. Authoritarianism. Democracy.

Artigo submetido em 31 de julho de 2020 e aprovado em 22 de dezembro de 2020.

* Doutor em Ciência da Religião pela UFJF. Professor PPGE Unimontes. País de origem: Brasil. E-mail: heiberle@hotmail.com 


\section{Introdução}

Diferentes pesquisadoras e pesquisadores já escreveram sobre as representações simbólicas nas dinâmicas de produção da política, não só evidenciando a mecânica das "invenções das tradições" (HOBSBAWN; RANGER, 1997), mas, também, abarcando a formulação de que Estados-Nação recorrem às "liturgias políticas" (RIVIÈRE, 1988) e “operam com representações sobre si e, em maior ou menor grau, através de práticas, enunciados e narrativas em meios próprios (...), mobilizam dispositivos e recursos simbólicos, procurando organizar uma coletividade, em torno dessas representações” (HORÁCIO, 2018), inclusive porque se as representações simbólicas são imprescindíveis às organizações (KERTZER, 1998), o "simbólico institui e reforça formas institucionais como Estados, partidos e estruturas político-sociais”. (CAMURÇA, 2008).

Muitos autores falam em "sacralização da política" e relacionam os processos supracitados com a ocorrência do surgimento de religiões da política ${ }^{1}$. (GENTILE, 2005a， p. 215; CATROGA，2005; BELLAH，1993; ARON, 1985; VOEGELIN, 2002; SIRONNEAU, 1985).

desse modo, os conceitos relacionados à religião da política (religião civil e religião política) têm sido acionados não só por aqueles que se interessam pelos simbolismos do poder, ou pelos que procuram fundamentos para a estética da política, mas, também, por aqueles que investigam “experiências políticas” que arrastam multidões e mobilizam símbolos, e por aqueles que refletem sobre a tematização indivíduo-comunidade e tratam a religião civil, por exemplo, como uma proposta, um projeto moral (BELLAH, 1999; 1993; MATA, 2000). Sendo que, nesse último caso, observam o conceito de religião civil "como um fator de legitimação e de consenso em uma sociedade pluralista e democrática, bem como um instrumento de educação cívica sobre a ética do bem comum”. (GENTILE, 2005a).

1 Este trabalho se ampara na categoria religião da política que abarca, e diferencia os conceitos de religião civil e de religião política, distinção que será explicitada mais adiante. 
No entanto, o emprego dos conceitos de religião civil e de religião política, que englobam a categoria de religião da política, também produz sempre grandes controvérsias e censuras, que vão desde questionamentos sobre a possibilidade da existência de religiões não confessionais, passando por críticas que acusam a ocorrência de certa imprecisão nas definições dos próprios conceitos (confundidos entre si, por exemplo), sendo que, nesse caso, há a denúncia de que os conceitos são utilizados de modo demasiadamente "flexíveis", atributo que colocaria em dúvida a capacidade operatória dos mesmos.

Além disso, alguns estudiosos denunciam a ausência de pesquisas empíricas que respaldem os conceitos de religião política e de religião civil, "a cujos propósitos proliferam mais as conceitualizações do que os dados empíricos²", segundo afirma um dos denunciantes, o pesquisador Claude Rivière (1989). Outros, como Albert Piette, reclamam a falta de uma metodologia segura que faça com que as pesquisas baseadas nas experiências históricas relacionadas aos conceitos em questão tenham alguma legitimidade, não se reduzindo a "utilização metodológica de analogia não testada e explorada empiricamente, uma finalidade teórica enviesada por alguns pré-juizos ideológicos e o uso discursivo de uma metáfora que resta sempre incerta”. (PIETTE, 1990, p. 205).

Juntam-se às críticas supramencionadas aquelas que advertem sobre a imprecisão conceitual ao se "confundir o problema da religião política com o problema da 'estética da política'” (GENTILE, 2005a, s/n) limitando o problema das religiões civis e políticas aos rituais e aspectos simbólicos e suas expressões estéticas.

Existem, também, posicionamentos (qualificados de substantivos e fenomenológicos) contrários à utilização dos conceitos de religião civil e política nas classificações de experiências históricas, porque alegam que esses conceitos

\footnotetext{
2 Alguns trabalhos recentes, além dos já clássicos, que de algum modo relacionam os conceitos com as experiências empíricas são os de: D. Bitusa (2008) sobre Israel; N. Guigou (2000) sobre o Uruguai ; H. Horácio (2014) sobre Cuba.
} 
não dão conta do que esses críticos chamam de "essência da religião", do Além, do pós-mortem e da imprescindibilidade da existência de um deus nas religiões ${ }^{3}$.

Em que pese à importância desses questionamentos supracitados, o objetivo desse artigo não é o de colocar, empiricamente, à prova esses conceitos, mas, delimitá-los, potencializando-os, visando melhores rendimentos em seus experimentos futuros.

Até porque, mesmo existindo diferentes questionamentos, os conceitos adquiriram relevância diante dos litígios surgidos após "nacionalismos religiosos e fundamentalismos teocráticos do século XX que deram origem a uma nova onda de estudos" que observaram uma "politização da religião" e uma "religiocização da política”. (GENTILE, 2005a). Bem como ganharam interesse em um momento em que a relação entre Estado e Religião(ões) no espaço público passou a ser vista como uma das grandes questões dos países contemporâneos. No Brasil, por exemplo, podem ser mobilizados para reflexões sobre a chegada ao poder, apoiado por lideranças e denominações religiosas, de um presidente que diz operar segundo o slogan "Brasil acima de tudo, Deus acima de Todos", e que teria sido um catalizador de uma espécie de "religião bolsonarista", isso segundo alguns pesquisadores.

Interesse que também pode ser observado pelos "trabalhos sobre a sociologia das religiões, onde não só a religião civil, mas também a religião política conquistaram recentemente o seu próprio espaço”. (GENTILE, 2005a)4. Isto se deu na Europa, conforme um dos grandes estudiosos desse tema, porque o conceito de religião política foi considerado com importantes rendimentos por autores como Jean-Jacques Wunenburger, Jean-Paul Willaime, Giovanni Filoramo e Claude Rivière, que “admitem a existência de formas genuínas de religiosidade política,

\footnotetext{
${ }^{3}$ Embora não seja essa a perspectiva de discussão deste artigo, importa destacar que a afirmação de Durkheim que diz que "a crença em deus transcendente não se encontra em todas as religiões", como, por exemplo, o Budismo e o Jainismo (LAZAR, 1994, p. 152).

${ }^{4}$ Segundo o estudioso do conceito da Religião da Política Emilio Gentile, "o crescente interesse no fenômeno das religiões políticas é provado pela publicação das revistas Movimentos totalitários e religiões políticas, iniciada em 2000 e dedicada a este assunto" (GENTILE, 2005a, s/n).
} 
como uma expressão de um fenômeno mais amplo de religião secular ou formas próprias de uma ‘ressacralização’ da sociedade moderna”. (GENTILE, 2005a).

Já o conceito de religião civil, por exemplo, voltou à cena quando surgiram consideráveis reflexões sobre a tematização indivíduo-comunidade em um momento histórico marcado por um individualismo radical que pode trazer prejuízos éticos e morais para os Estados, segundo apontam alguns autores, como Robert Bellah (1999).

Sobre Robert Bellah, autor que contribuiu significativamente para o aumento do interesse pelo estudo do conceito de religião civil, foi a sua interpretação do conceito, mobilizada “após as reações provocadas pela retórica religiosa do presidente George W. Bush e ao ataque terrorista de 11 de Setembro de 2001", que resultaram "no despertar do patriotismo americano, bem como o efeito do que foi recentemente definido como o retorno da religião para a praça pública". (GENTILE, 2005).

Outro elemento que permeia os debates sobre esses conceitos, além das questões supracitadas e das demandas oriundas delas, é que esses conceitos são sempre pensados dentro de um marco específico do paradigma da secularização. (GENTILE, 2005b, p. 260).

A respeito desse paradigma, Danièle Hervieu-Léger sintetiza bem a discussão sobre ele dentro da sociologia. A autora menciona que há uma compreensão de "determinada teoria da modernidade que articula, como duas dimensões de um único movimento, a trajetória histórica da racionalização e a afirmação do sujeito autônomo" que resultaria no "despojamento dos deuses" e no “desmoronamento da 'empresa humana de criação de um cosmos sagrado”. (1997, p. 31-32). Segundo a autora,

a modernidade vivida apresenta-se como a experiência de um mundo cambiante, mutável, diferenciado, como a experiência de um mundo por fazer. Esta crise da visão religiosa de um mundo unificado encontra-se em relação dialética (ao mesmo tempo ela vem dele e o torna possível) com o processo histórico que Weber e Parsons (entre outros) descreveram como 
sendo o da diferenciação das instituições e, muito especialmente, com o processo jurídico-político da emergência do Estado. $O$ avanço da laicização, a separação (mais ou menos marcada, conforme os países) das Igrejas e do Estado manifestam, no plano jurídico e institucional, a perda de influencia das instituições religiosas sobre a sociedade. $O$ próprio campo religioso torna-se um campo institucional especializado e a religião um fragmento da cultura. (HERVIEU-LÉGER, 1997, p. 32).

Se tratando do processo supramencionado, reflexões sobre a secularização vão ser desenvolvidas por diferentes autores contemporâneos, alguns dos quais mobilizadores dos conceitos de religião civil e de religião política.

O debate hodierno a respeito da compreensão do processo de secularização possui distintas perspectivas 5 , sendo que existe aquela que considera que a secularização pode ser entendida como "mundanização" dos valores religiosos, “como no caso de R.N. Bellah com seu conceito de religião civil” (GARCIA, 2005), aquela em que a "religião aparece como subsistema social, mas sem capacidade de cumprir a velha função integradora que caracterizava as velhas éticas religiosas”, há aquelas que observam níveis distintos da secularização, e outras que interpretam a secularização como o declínio da religião no mundo moderno, declínio resultante da falta de plausibilidade e significação social, entre esses autores destaca-se Peter Berger, Steve Bruce e Brian Wilson. (GARCIA, 2005).

Entre os pesquisadores que consideram a presença, ou o retorno, da religião à esfera pública, há aqueles que observam a existência de uma função de integração da religião nas sociedades diferenciadas, e aqueles que não concordam com essa função integradora, embora compreendam que a secularização não pode mais ser interpretada como privatização da religião. Assim, os primeiros admitem a possibilidade da existência de religiões civis (Bellah), enquanto os segundo não veem viabilidade no conceito de religião civil, embora vejam a institucionalização

\footnotetext{
${ }^{5}$ Segundo Tschannen, os teóricos do paradigma da secularização tem em comum o compartilhamento do processo de diferenciação, "este autor entende que dita teorização sobre secularização tem seu fundamento em uma comunidade de investigação identificável. Os autores portadores desse paradigma são B. Wilson, K. Dobbelaere, R. Fenn, T. Luckmann, D. Martin, P. Berger, T. Parsons e R.N. Bellah. Ainda que esse três últimos não pertençam a dita comunidade de investigação, $O$. Tschannen os considera como portadores passivos do paradigma já que a maior parte de suas formulações teóricas tem sido aceitas pelos portadores ativos de dito paradigma". (GARCIA, 2005, p. 147).
} 
no público dos valores religiosos, ou o retorno das religiões à esfera pública e a desprivatização da religião (Casanova e Parsons, Habermas ${ }^{6}$ ), bem como o “aparecimento” de religiões públicas.

\section{Religião pública de José Casanova}

José Casanova, que mobiliza o conceito de religião pública para tratar da dinâmica da desprivatização das religiões, considera que não existem motivos para associar diferenciação com privatização. Segundo Casanova, a desprivatização "é o processo pelo qual a religião abandona seu lugar assinalado na esfera privada e entra na esfera pública indiferenciada da sociedade civil, tendo como objetivo tomar parte no processo contínuo de disputa, legitimação discursiva e limites recusados". (CASANOVA, 1999, p. 161).

Ademais, Casanova indica que a desprivatização é uma via de mão dupla, que se por um lado a religião reivindica a sua entrada na esfera pública, por outro, as coisas públicas, e outros públicos, forçam as suas entradas no âmbito privado, interno, das religiões. Assim são os casos dos movimentos "para transformar os abusos privados em escândalos públicos”. (CASANOVA, 2012). Segundo ele, dando como exemplo "o surgimento de discursos feministas religiosos", o processo mencionado acima:

Implica não apenas atores religiosos trazendo normas religiosas para a esfera pública secular, mas também normas seculares, em particular normas seculares de igualdade de gênero, inevitavelmente entrando e afetando a esfera religiosa. Somente através da segregação radical sectária da sociedade e do mundo, uma comunidade religiosa pode evitar a influência secular. Sob condições de globalização, nenhuma tradição religiosa, nem mesmo aquelas com reivindicações globais, podem estar imunes à opinião pública global. (CASANOVA, 2009, p. 21, tradução nossa).

\footnotetext{
${ }^{6}$ Philippe Portier indica que Habermas demonstra "um resgate do religioso como componente importante na estruturação de um espaço público pós-secular. A razão disto encontra-se no fato que a religião, segundo Habermas, constitui uma reserva de valores éticos e culturais que podem eventualmente reforçar a consciência das normas e a solidariedade dos cidadãos e um contexto de crise da razão secular" (2003).
} 
Para Casanova, a religião pública, que faz parte do processo de desprivatização, se dá quando a religião assume funções políticas na modernidade e "passa a atuar em três distintas arenas: quando se insere no aparato de Estado, quando penetra o sistema político e quando se transforma em uma força política mobilizadora no nível da sociedade civil”. (MONTERO, 2016). José Casanova adverte que

os cientistas sociais, como atores práticos, e como teóricos envolvidos em fazer "distinções" e traçar limites, necessitam desenvolver critérios analíticos e normativos para diferenciar diferentes formas de religião pública, e distinguir suas possíveis consequências sócio-históricas. Porém, sobretudo, os cientistas sociais precisam reconhecer que, além de todas as forças estruturais, as pressões legítimas e as diversas razões válidas que no mundo moderno e secular empurram a religião para a esfera privada, a religião continua tendo - e provavelmente continuará tendo - uma dimensão pública. As teorias da modernidade, as teorias da política moderna e as teorias da ação coletiva que sistematicamente ignoram essa dimensão pública da religião moderna são, necessariamente, teorias incompletas. (CASANOVA, 1999, p. 161-162).

No entanto, vale destacar que José Casanova, mesmo observando o processo de desprivatização e das religiões públicas, recusa o modelo republicano que, separando esferas pública/privada, considera a possibilidade de uma religião civil "concebida como força normativa integradora da comunidade política e social”. (MONTERO, 2016). Montero (2016) menciona que Casanova rejeita esse modelo porque "o problema que a tradição republicana coloca é o risco da perda da autonomia da esfera política implicado nessa contração entre comunidade política e comunidade nacional”.

Em trabalho recente, relacionado aos conceitos de religião civil e de religião pública7, a pesquisadora Paula Montero (2016) indica que se o ponto forte da religião civil está relacionado à possibilidade de "pensar uma ideia de civis fundada

\footnotetext{
7 No referido trabalho, a pesquisadora observa que outra variante de religião pública, seria, de alguma forma, a "religião cívica", conceito que utilizado pelos historiadores medievalistas, está relacionado à dinâmica "da apropriação de valores inerentes à vida religiosa pelos poderes urbanos, para fins de legitimação, de celebração e de salvação pública". (2016). Segundo Paula Montero, "o ponto forte do conceito de religião cívica é o de chamar a nossa atenção para os processos de apropriação de elementos reconhecidos como religiosos - no caso, ritos, santos regionais e lugares até então controlados pela hierarquia da Igreja Católica - e para sua importância como forma de legitimação do poder seja burguês, seja estatal”. (MONTERO; 2016).
} 
no religioso, e, ainda assim, secular, porque não referida a nenhuma comunidade de culto", a religião pública de Casanova tem como ponto forte "a proposição de que os processos de secularização não necessariamente redundam em menos religião.”, sem contar o fato de que o conceito de religião civil pode até ser considerado como um equivalente/variante de religião pública.

No entanto, eles se diferenciam significativamente porque Casanova, por exemplo, vê como desnecessária/impraticável a concepção funcionalista da imprescindibilidade da integração da sociedade/nação por uma religião civil, como também considera perigosa a possibilidade da generalização de valores e ideias religiosas, inclusive para a suposta integração, levantada pela religião civil de Robert Bellah ${ }^{8}$.

\section{Religião Civil}

A respeito do "recuperador" do conceito de religião civil, Robert Bellah, ele é, de algum modo, representante de uma chave de leitura aberta por Rousseau, que na obra Contrato Social9 indica a necessidade de uma religião civil como mecanismo de fortalecimento do contrato social e de certo tipo de sociabilidade. Sendo que, para Rousseau, a religião civil tem como dogmas positivos "a vida futura; a felicidade dos justos; o castigo dos maus; a santidade do contrato e das leis” (ROUSSEAU, 2007, p. 118), e aparece como

uma profissão de fé puramente civil. Cujos artigos compete ao soberano fixar, não precisamente como dogmas de religião, mas como sentimentos de sociabilidade, sem os quais é impossível ser bom cidadão ou súdito fiel. Sem poder obrigar ninguém a crer neles, pode banir do Estado quem neles não acreditar. Pode bani-lo não como ímpio, mas como insociável, como incapaz de amar sinceramente as leis, a justiça, e de imolar em caso de

\footnotetext{
${ }^{8}$ Ademais, Paula Montero (2016) considera que o conceito de religião pública muito mais abrangente, uma vez que compreende dinâmicas distintas, instáveis, conflituosas, relacionadas aos diferentes modos como a religião pode assumir funções políticas e ações públicas, que vão desde ela exercendo funções partidárias, ou permeando as estruturas do Estado, até a ações da religião na sociedade civil.

${ }^{9}$ Embora já em John Locke possa-se constatar "a necessidade de mobilização consciente e instrumental dos sentimentos". (BARBOZA FILHO, 2008, p. 20-21). Além disso, conquanto a ideia de Religião Civil apareça no Contrato Social de 1762, já em agosto de 1756 encontra-se a primeira referência ao conceito de religião civil em uma carta que Rousseau escreveu para Voltaire. (CATROGA, 2005, p. 509.)
} 
necessidade sua vida a seu dever. Se alguém depois de haver reconhecido publicamente esses mesmos dogmas, comporta-se como se não acreditasse neles, que seja punido de morte, pois cometeu o maior dos crimes: mentiu perante as leis. ${ }^{10}$ (ROUSSEAU, 2007, p. 152).

Robert Bellah, a despeito da importância da chave aberta por Rousseau, foi influenciado pelas perspectivas de Durkhiem e Tocqueville, sendo que Durkheim, “por exemplo, considera possível a reação ao individualismo e a superação da anomia com o reforço às regras e à moralidade da divisão de trabalho através das corporações ou às crenças e sentimentos comuns sintetizados na religião. (LEITE, 1998, s/n.).

Já Tocqueville, observara nos Estados Unidos “a correção da predominância do puro interesse pela presença da cooperação social”, pois entendera que a "legitimidade desta sociedade do interesse bem compreendido encontra-se profundamente enraizada numa 'religião civil', ou seja, na dimensão dos sentimentos”. (BARBOZA FILHO, 2008, p. 22). Tocqueville, em viagem aos Estados Unidos, observou na religião organizada "uma instituição política que contribui potencialmente para manter uma república democrática na América” (TOCQUEVILLE, 1985, p. 193), até porque, para o autor, o puritanismo foi tanto uma teoria política, quanto uma doutrina religiosa, sem contar que foi, o puritanismo, uma das primeiras e grandes denominações nos Estados Unidos. (TOCQUEVILLE, 1985, p. 193).

Robert Bellah, leitor de Tocqueville, e importante pensador sobre a relação individualismo e comunitarismo como estruturas chaves para compreensão dos Estados Unidos, e autor “- de raízes durkheimiana- se baseia na convicção de que a sociedade deve descansar em um conjunto de valores comuns e normas institucionalizadas”. (BÈJAR, 1996, p. 79).

\footnotetext{
${ }^{10}$ Rousseau indicava a existência de três tipos de religiões: 1- a religião do homem (ou religião natural) que é a religião do Evangelho, "o verdadeiro teísmo", 2- a religião do cidadão (religiões dos "primeiros povos"), que Rousseau chama de direito divino civil ou positivo e que Catroga identifica como as religiões pagãs da pólis e do Império, e mesmo o judaísmo e o islamismo. 3-religião sacerdotal (o cristianismo histórico). A religião civil de Rousseau é uma espécie de síntese entre a primeira e a segunda (religião do homem e a religião do cidadão) excluindo a terceira, pois, a primeira do verdadeiro evangelho faz com que os homens se reconheçam todos como irmãos e que por isso nada dilacere a sociedade que os une e, a segunda é contentora do "culto divino ao amor das leis" e cultua a pátria como cultua Deus, enquanto a terceira, recusada por Rousseau, nega a unidade social, pois "dá aos homens duas legislações, duas cabeças, duas Pátrias, e os curva a deveres contraditórios, tolhendo-lhes ser a par devotos e cidadãos." (ROUSSEAU, 2007, p. 115).
} 
Segundo a pesquisadora Márcia Pereira Leite, "Bellah pensa os vínculos entre indivíduo e sociedade, enfatizando a dinâmica propriamente cultural e, nesse sentido, reinventa a religião civil a partir da fraternidade, da solidariedade e do exercício do civismo na sociedade civil”. (1998, s/p). Robert Bellah observa uma “dimensão religiosa pública que estaria na intercessão da institucionalização oficial governamental dos Estados Unidos, que pode ser percebida com frequência nas referências religiosas nos primeiros documentos oficiais e nos documentos atuais das estruturas governamentais" (HORÁCIO, 2013), bem como na existência de pais fundadores e seus mitos de fundação (in God we trust) e destino manifesto, até as venerações de heróis cívicos em rituais, narrativas e imaginários mencionando-os como um "povo eleito". (HORÁCIO, 2013).

Bellah compreende uma religião civil nos Estados Unidos que não é anticlerical, que extrai da tradição religiosa determinadas narrativas éticas e de coesão, e que possui um conjunto de crenças e de símbolos "a que nem sequer faltam os seus profetas e os seus mártires, os seus grandes acontecimentos e os seus lugares de memória, nem práticas rituais que pontualizam o calendário cívico através de selecionadas evocações, as quais, nas suas diversidades, põem em cena uma autorrepresentação da América.” (BELLAH, 1993, p. 5).

Para Nicolás Guigou, a religião civil dos Estados Unidos não tenta "substituir as religiões existentes (caso da religião civil francesa), senão que se apropria e toma seus valores e simbologia da religião fundante, embora os dilua enquanto simbologia e valores da nação." (GUIGOU, 2000, s/n). E, de acordo, com Bruno Reinhardt, referindo a um artigo de Bellah, de 1970, p. 171-172:

os axiomas político-teológicos que sustentam o imaginário da religião civil americana são: i) os valores formativos dos Estados Unidos (tais como liberdade, igualdade e justiça) têm uma base transcendental; ii) a soberania da nação norte-americana é atribuída, em última instância, a Deus, situando-se além da vontade geral e de outros centros discursivos típicos da modernidade secular; e iii) os EUA são responsáveis por portar este desejo providencial de Deus na terra. (REINHARDT, 2011, p. 29). 
A respeito do conceito de religião civil, como aparece na citação acima de Nicolás Guigou, importa destacar que ele também é mobilizado para os casos francês ${ }^{11}$ e uruguaio (CATROGA 2006, 2005; GUIGOU, 2000), sendo ambas as experiências tidas como democráticas, diferente do conceito de religião política, que sempre é mobilizado relacionado às experiências do nazismo, fascismo e do stalinismo.

Como é justamente o objetivo desse trabalho evidenciar a diferenciação necessária que deve ser feita entre um conceito e outro, ou seja, entre o conceito de religião civil e religião política, posteriormente apresentar-se-á essa distinção, não antes da apresentação do conceito de religião política.

\section{Religião política}

O conceito de religião política está intimamente ligado às experiências políticas autoritárias que ocorrem no século XX, embora a expressão possa ter aparecido antes na Revolução Francesa e fora mencionada, por exemplo, por Abraham Lincoln em 1838,

só depois que ela foi associada com o fascismo, bolchevismo e o nazismo e no início de análises comparativas desses regimes, que o conceito de religião política tornou-se mais proeminente. Foi empregado para definir a exaltação absoluta do partido e do Estado, o culto ao líder, o fanatismo de massa, ritos e símbolos de liturgias coletivas, que eram aspectos fundamentais dos novos regimes totalitários. (GENTILE, 2005).

\footnotetext{
${ }^{11}$ A Religião Civil francesa, de acordo com Catroga, "foi sendo dotada do seu Panteão, da sua martiriologia, da sua hagiografia, da sua liturgia (multiforme e ambígua), dos seus templos, das suas estátuas, frescos e nomes de rua, dos seus manuais escolares, dos seus mitos e ritos, tudo colocado ao serviço de uma prática educativa que se queria permanente". (2005, p. 565). Ela lançou mão de uma simbologia rito-mítica que objetivava levar "as consciências a interiorizarem, como imperativos ético-cívicos, os direitos e deveres", e buscou, como toda religião civil, "desatomizar os indivíduos". No entanto, diferente dos Estados Unidos, de uma religiosidade cívica teísta, a religião civil francesa também não possuiu a narrativa do julgamento final, de imortalidade da alma e nem a invocação de deidades, atributos fundamentais de uma religião civil para Rousseau, além de recorrer ao sentido "objetivo e progressista da história" e não à graça divina como a dos Estados Unidos. (CATROGA; 2005; 2006).
} 
Entre os autores pioneiros na utilização do conceito de religião política, pode-se mencionar Eric Voegelin ${ }^{12}$ em seu ensaio de 1938, que é um registro dos primórdios do nazismo. Nele, escreve Voegelin:

O poder do Estado ser originário ou absoluto deixa de ser um juízo de um sujeito conhecedor, tornando-se no dogma de um crente. A existência do homem perde uma parte da realidade na sua vivência própria, o Estado restitui-lha a afirma-se como o único real verdadeiro, do qual emana um fluxo de realidade para os homens e os faz reviver de maneira englobante, como as partes de uma realidade sobre-humana. Penetramos aqui no coração de uma experiência religiosa, e as nossas palavras descrevem um processo místico. (VOEGELIN, 2002, p. 27).

Voegelin faz parte do grupo de autores que compreende que a política como religião é um tipo de "transfiguração do sagrado" em um "fenômeno que pode ser rastreado até as épocas mais remotas" (GENTILE, 2005), mas que na contemporaneidade possui traços peculiares. Para ele,

quando o próprio Deus se torna invisível para o mundo, são os sentidos deste mundo que se tornam divinos, quando os símbolos da religiosidade supramundana são banidos, são os novos símbolos, nascidos da linguagem científica intramundana, que tomam seu lugar. A comunidade intramundana reconhece o seu apocalipse do mesmo modo que a Eclésia cristã, com a única diferença que os seus anunciadores modernos dão relevo às suas criações simbólicas dos juízos científicos. (VOEGELIN, 2002, p. 69).

Além de Voegelin, vários são os autores que apontam na sociedade contemporânea uma "transferência do sagrado do domínio religioso para o temporal” em que o político aparece como "um domínio privilegiado de transferências mítico-religiosas”. (SIRONNEAU, 1985, p. 264). Para os autores que observam "uma correlação entre a secularização e a compensação pelas religiões políticas" (RIVIÈRE, 1988, p. 17), o “deslocamento" acima tem como consequência o surgimento de religiões seculares, sendo a religião política considerada como principal expressão das manifestações dessas religiões.

\footnotetext{
12 "Ainda hoje, muitos estudiosos atribuem sua origem a Voegelin, a Aron ou a Gurian. Por uma questão de fato, como já demonstrado em meu livro sobre as religiões da política, a criação do conceito de religião política não diz respeito a esses estudiosos..." (...) No final desta década o conceito de religião secular ou política já estava no arsenal dos principais estudiosos do totalitarismo, como Frederick Voigt, Cobban Alfred, Morstein Fritz Marx, Hans Kohn, Hayes Carlton, Borkenau Franz Neumann e Sigmund" (GENTILE, 2005a).
} 
No final da década de 1930, os termos em questão, e o de Religião Secular que "possui um significado semelhante ao de religião política", já "estava(m) no arsenal dos principais estudiosos do totalitarismo" (GENTILE, 2005). Entre os estudiosos que utilizavam esses conceitos, Raymond Aron ${ }^{13}$ empregou o conceito de Religião Secular ${ }^{14}$ para qualificar determinadas "doutrinas sociais e políticas" como religiosas. Embora tenha se ocupado majoritariamente do "socialismo", Aron compreendeu como "religiões seculares os movimentos políticos que instituem os mesmos comportamentos que as religiões estabelecem aos crentes, ou, ao comportamento que os indivíduos constituem com as religiões”. (HORÁCIO, 2013). Nas palavras do próprio Aron: “eu proponho chamar 'religiões seculares' as doutrinas que penetram nas almas dos nossos contemporâneos no lugar da fé evanescida e situam-se aqui, no remoto futuro, sob a forma de uma ordem social a criar a salvação da humanidade”. (ARON, 1985, p. 370).

De acordo com o pesquisador espanhol Santiago Garcia, embora o stalinismo e o nazismo não tivessem como objeto de culto uma realidade transcendente, essas doutrinas (termo atribuído a Aron) eram catalogadas por Aron como religiões pelos seguintes motivos: "a) estabeleciam um objetivo último de natureza quase-sagrada; b) proporcionavam à existência humana uma orientação diante do mundo similar as das religiões históricas; c) explicavam as catástrofes a partir de uma interpretação global do mundo; d) integravam os indivíduos em comunidades fraternais que antecipavam a comunidade futura da humanidade salva e em função disso exigiam sacrifícios" (GARCIA, 2005, p. 172). De acordo com Aron, essas doutrinas "fixam o objetivo último, quase sagrado, em relação ao qual se definem o bem e o mal”. (ARON, 1985, p. 370).

\footnotetext{
${ }^{13}$ Segundo o pesquisador Santiago Garcia, "efetivamente, foi R. Aron, em um artigo em 1944, o primeiro autor que utilizou o conceito de 'religião secular" (GARCIA, 2005, p. 172).

${ }^{14}$ Vale pelo menos mencionar a possibilidade aberta por Albert Piette (1993, p. 123) que desenvolveu o conceito de Religiosidades Seculares. Piette observa a hipótese de perceber estas religiosidades como a presença, "em uma atividade secular de traços das religiões existentes". 0 autor indica que as religiosidades seculares são religiões potenciais, inseridas no intervalo entre as atividades religiosas e seculares, em um processo de oscilação entre as duas dimensões. As religiosidades seculares imitam os traços característicos das religiões estabelecidas, bem como se regulam em relação a elas. Por isso, as religiosidades seculares resultam de processos sincréticos ou "bricolados", em que, de acordo com o autor "no processo sincrético, o traço religioso constitui um recurso epistemológico, temático, teórico e ritual, com uma função sobretudo cognitiva, legitimadora, distintiva e mobilizadora. Ela resta uma última forma possível de sincretismo: com efeito, uma montagem de traços característicos do religioso, escolhidos e praticados em diferentes atividades seculares, de tal sorte que existe uma religião secular bricolada.
} 
Enfim, nas suas estruturas mesmas, estas doutrinas reproduzem certos traços característicos dos dogmas antigos. Elas também dão uma interpretação global do mundo (pelo menos mundo histórico). Elas explicam os sentidos das catástrofes que atravessam a humanidade infeliz, elas deixam aperceber, distante, o resultado das trágicas provas. De agora elas asseguram, na comunidade fraterna do partido, a antecipação da comunidade futura da humanidade salva. Elas exigem os sacrifícios que, no instante mesmo, são pagos: elas arrancam o individuo da solidão das multidões sem alma e da vida sem esperança. (ARON, 1985, p. 370).

Jean Pierre Sironneau foi um dos autores que deu continuidade às reflexões de Aron, indicando "que interessa, é compreender o impacto que tem às vezes sobre as multidões ocidentais as diversas formas de socialismos ou de fascismos, e de refletir sobre o futuro das religiões seculares, sobre suas possibilidades ou não de satisfazer a vida espiritual da nossa sociedade”. (SIRONNEAU, 1982, p. 206). De acordo com Jean-Pierre Sironneau,

ambos movimentos contavam com expressões próprias dos fenômenos religiosos: estruturas míticas em seus núcleos ideológicos, comportamentos rituais mais ou menos análogos aos das religiões históricas, presença de formas de sociabilidade de tipo comunal próximas a das comunidades religiosas, e uma adesão absoluta que recorda a fé religiosa. (GARCIA, 2005, p. 173).

Para Sironneau, as "religiões políticas tiveram sua gênese em condições sociais similares às que têm dado lugar aos milenarismos: desequilíbrios sociais, grandes doses de frustração, surgimento de líderes carismáticos e, especialmente, presença de estruturas míticas centradas na regeneração e na salvação". (GARCIA, 2005, p. 173). Assim, "as religiões políticas amenizam a angústia das pessoas no seio da sociedade”, bem como orientam as ações das pessoas (HORÁCIO, 2013) "para pólos quase-trancendentes (as noções de raça, classe, partido) dando um certo sentimento de plenitude pela identificação ao grupo onde o indivíduo se funde, tornando a encontrar o sentimento tipicamente religioso da dependência absoluta com relação ao poder" (SIRONNEAU, 1985, p. 270).

Pode-se observar, após leitura dos autores supracitados (Voegelin, Aron, Sirroneau, Gentille, Garcia, Rivière), que o conceito de religião política foi mobilizado majoritariamente para reflexões sobre as experiências classificadas, pelos pesquisadores, como autoritárias, enquanto o conceito de religião civil para 
os casos dos Estados Unidos e da França, classificadas como experiências democráticas.

Essa demarcação é um dos parâmetros teórico-metodológicos que colaboram para que este artigo alcance o seu objetivo estabelecido, qual seja, fazer uma relação dos conceitos de fundamentalismo, religião civil e religião política, após estabelecer uma distinção entre esses dois últimos conceitos, distinção não só baseadas nas definições dos pesquisadores supracitados, mas, ainda, tendo como parâmetros as atitudes e relações que as experiências políticas representadas por esses conceitos "possuem com respeito às religiões tradicionais, e sua maneira de considerar a relação entre a autoridade e a liberdade, o individuo e o Estado”. (GENTILE, 2005b, p. 15).

\section{Distinção entre religião civil, religião política e o fundamentalismo}

Mantendo relações com os critérios supracitados, para a distinção entre os conceitos, há outros parâmetros que podem ser articulados, como menciona, por exemplo, Claude Rivière, que estabelece a distinção entre religião civil e religião política destacando que "os regimes autoritários que fazem do político uma religião (religião política), e os regimes democráticos que utilizam as religiões como elemento de sustentação do político (religião civil)”. (RIVIÈRE, 1988, p. 144). Outro exemplo dessa diferenciação foi estabelecido por R.C. Winberley onde:

[a] distinção entre religião política e civil, realizada por R.C.Wimberley, seria delineada através de três traços principais: 1- nas religiões políticas, o elemento religioso estaria contido na sacralização da ordem política existente; nas religiões civis, ele seria proveniente de um laço entre essa ordem e um poder transcendente, na base das crenças religiosas variadas professadas por essa sociedade; 2- nas religiões políticas, o poder afirmaria sua autoridade, não apenas no domínio político, mas em toda a vida social; nas religiões civis, o poder limitar-se-ia ao domínio político; 3nas religiões políticas, existiria um sistema específico de valor e de normas; nas religiões civis, seu conteúdo teria tal nível de generalidade que não entraria em conflito nem com as religiões, nem com as normas políticas. (RIVIÈRE, 1989, p. 144). 
No caminho da distinção entre os dois conceitos, sobretudo relacionado aos tipos de regimes políticos (democráticos ou ditatoriais) em que eles emergem, Gentile menciona uma caracterização significativa, pois, para ele, enquanto a:

Religião civil é uma forma de sacralização de uma entidade política coletiva que não se identifica com a ideologia de um movimento político em particular, afirma a separação entre Igreja e Estado, e, apesar de postular a existência de um ser sobrenatural deisticamente concebido, convive com tradicionais instituições religiosas sem se identificar com qualquer uma confissão religiosa particular, apresentando-se como um credo comum cívico acima dos partidos e confissões. [Que] reconhece uma ampla autonomia tanto para o indivíduo quanto para a coletividade santificada, e geralmente apela para consenso espontâneo para observar os mandamentos da ética pública e a liturgia coletiva. (GENTILE, 2005b).

\section{A religião política,}

é uma forma de sacralização da política de caráter exclusivo e integralista. Ele rejeita a coexistência com outras ideologias e movimentos políticos, nega a autonomia do indivíduo no que diz respeito ao coletivo, prescreve a observância obrigatória dos seus mandamentos e participação em seu culto político, e santifica a violência como um braço legítimo da luta contra os inimigos, e como instrumento de regeneração. Ele adota uma atitude hostil em relação a religiões tradicionais institucionalizadas, procurando eliminá-los, ou procurando estabelecer com eles uma relação de coexistência simbiótica, no sentido de que a religião política procura incorporar a religião tradicional dentro de seu próprio sistema de crenças e mitos, atribuindo-lhe um papel subordinado e auxiliar. (GENTILE, 2005b).

O pesquisador Emilio Gentile, que embora perceba que determinadas situações históricas podem ser pensadas através da junção dos dois conceitos, procurando salvaguardar as peculiaridades de cada um deles, opta por catalogá-los (religião civil e política) como categorias distintas dentro do conceito de religiões da política (GENTILE, 2005b, p. 16). Onde, para Gentile, se o fato de ambas serem fenômenos modernos, que pressupõe a secularização, e a separação entre o Estado e as religiões, o que as diferencia é que na religião política a "forma de sacralização" é baseada em "monismo ideológico", que não permite a existência de outras concepções, no monopólio do poder, na busca pelo controle de todos os aspectos da vida individual e coletiva. (2005b, p. 260). Enquanto, 
por religião civil, nós entendemos as formas de sacralização de um sistema político que garante a pluralidade das ideias, a livre competição pelo exercício do poder e a revogabilidade dos governantes de parte dos governos graça aos métodos pacíficos e constitucionais: a religião civil, por consequência, respeita a liberdade do indivíduo, coexiste com as outras ideologias, não impõe a adesão obrigatória e incondicional as suas próprias leis. (GENTILE, 2005b, p. 260).

O pesquisador Fernando Catroga, em um entendimento que se aproxima ao de Gentile, observa que a Religião Civil das sociedades demoliberais (termo utilizado pelo próprio pesquisador português) "não se identifica com qualquer movimento político e partidário particular, ao mesmo tempo que procura respeitar a autonomia do indivíduo dentro da sociedade", além de consentir "iniciativas próprias da sociedade civil, numa coexistência pacífica com várias ideologias" e com as religiões tradicionais. Sua ação tem como objetivo "a interiorização, o menos coativa possível, de um credo mínimo que visa firmar as relações sociais e o consenso". (CATROGA, 2006, p. 138).

Já a religião política, de acordo com Catroga, busca sacralizar uma ideologia, reivindica a posse absoluta da verdade e não aceita conviver com outras ideologias, possuindo uma relação com as religiões tradicionais pouco pacíficas, onde: “aquela, ou procura eliminar estas últimas, ou, mediante acordos tácitos com elas, almeja integrá-las no seu próprio sistema de crenças e de mitos, reservando-lhes uma função meramente subordinada e auxiliar”. (CATROGA, 2006, p. 139).

Observadas as distinções acima, podem-se sintetizá-las compreendendo que a religião civil seria proveniente de um laço entre o poder e um dispositivo transcendente de crenças variadas, onde o poder político estaria limitado ao domínio político. Seu conteúdo, devido ao nível de generalidade, não conflitaria com as normas religiosas nem com outros conteúdos políticos, e se configuraria por sacralizar uma entidade política que não se identifica com um movimento político particular, apresentando um credo comum cívico acima dos partidos. Ademais, a religião civil reconhece uma autonomia para a coletividade e consente iniciativas 
próprias da sociedade civil, bem como promove uma coexistência pacífica com várias religiões e ideologias.

A respeito das definições de religião política supracitadas, pode-se constatar que, conforme indicam os autores, nas experiências políticas em quem elas existem, o poder afirma sua autoridade em todos os âmbitos da vida social, há um sistema específico de valor e normas, o poder político rejeita a coexistência com outras ideologias e movimentos políticos, nega a autonomia do indivíduo no que diz respeito ao coletivo, santifica a violência como um braço legítimo e, em alguns casos, é hostil às religiões tradicionais ou busca integrá-las no seu próprio sistema, em procedimentos que podem ser considerados fundamentalistas.

\section{Religião política e fundamentalismo}

De antemão, torna-se imprescindível também certa delimitação em torno do conceito de fundamentalismo, pois, o que não faltam são advertências que dizem que ele tem sido inflacionado, usado de maneira imprecisa e de forma indiscriminada. Há também advertências que destacam que esse conceito é muitas vezes usado de modo rotulatório, objetivando a criação de imagens pejorativas para aqueles que de alguma forma se diferenciam do rotulador. (PIERUCCI, 2006; DREHER, 2002). Mas, há também, definições mais restritivas, associando necessariamente fundamentalismo às expressões religiosas que possuem livros sagrados ${ }^{15}$.

No caso da articulação do conceito de fundamentalismo com o de religião política, é evidente que este último não se refere a "tradição do livro", e que para considerar uma religião política como fundamentalista é necessário reconhecer a perspectiva de que há religiões seculares, bem como reconhecer que, embora o conceito de fundamentalismo seja datado - de 1920 por Curtis Lee Laws, na

\footnotetext{
15 “Isso posto, o primeiro corolário que se segue é duplo: só quem é religioso pode ser fundamentalista; além disso, é preciso que essa religião possua um texto sagrado. Não é possível ser fundamentalista em uma religião que não tenha um livro sagrado. Ou seja, não dá para ser umbandista fundamentalista, pois não há na umbanda um livro inspirado por algum orixá que tenha o status e a chancela de ser um texto divinamente revelado. Dito de outra forma, o fundamentalismo se origina na crença de que há uma palavra escrita que é revelada - uma escritura sagrada". (PIERUCCI, 2006, p. 06).
} 
Northern Baptist Convention ${ }^{16}$-, há a possibilidade de concebê-lo no plural, devido, por exemplo, ao fato de que esse conceito no plural, evidencia "a necessidade de fugirmos à homogeneização, pois eles podem se expressar no âmbito religioso em toda a sua diversidade e para além dele". (DUARTE, 2013, p. 8). Pois

o termo fundamentalismo tem perpassado a reflexão de distintos pensadores nas últimas décadas. Sua utilização tem servido para justificar atitudes religiosas fanáticas, um retorno à sociedade pré-moderna ou mesmo práticas violentas. É imprescindível que esse termo seja usado no plural, porque existem diferentes fundamentalismos. Sua origem histórica encontra-se no universo religioso, entretanto, a sua abrangência na sociedade atual ultrapassa esse universo e ocupa o espaço da política e da economia, carregando consigo um traço claramente ideológico. Ter consciência de sua pluralidade é resguardar as várias especificidades que o fenômeno vem produzindo. (PANASIEWICZ, 2018).

Ao falar de fundamentalismo, "isso não significa afirmar, porém, a inexistência de uma dinâmica particular a cada expressão fundamentalista" (DUARTE, 2013, p. 8), bem como não significa negligenciar a necessidade da compreensão de que qualquer uso ou exame desse conceito tem que estar atento ao processo de rotulação existente nas dinâmicas conflitivas e de disputas, entre diferentes movimentos e expressões.

Ademais, a despeito das especificidades de cada experiência, resta compreender que há traços comuns nessas experiências que permitem, de algum modo, a remissão ao conceito de fundamentalismo. Como, por exemplo, nas palavras de L. Gerring (2009), "o que os fundamentalistas têm em comum não é um conjunto de crenças específicas, mas a atitude de mente. É a convicção de que possuem o conhecimento absoluto da verdade, de qual se tornaram guardiões divinamente ordenados".

No caso do "stalisnimo" - que juntamente com o nazismo e outros regimes autoritários do século XX são tidos como religiões políticas - diferentes autores supracitados observam nele uma organicidade em que o Estado/Partido é visto

\footnotetext{
${ }^{16}$ Oro (1996) assinala que o termo foi cunhado na Nicarágua em 1895, em uma conferência bíblica.
} 
como inquestionável, órgão infalível à formação do "Homem Novo", à chegada do “tempo novo”, em narrativas que podem ser compreendidas sob a clássica definição de estrutura milenarista:

Um movimento milenarista é definido pelos seguintes traços: a promessa de uma salvação terrestre e coletiva; promessas e objetivos de caráter ilimitado (outro mundo, outra sociedade, outro tipo de homem); a necessidade de uma ruptura violenta, de uma catástrofe ou de um cataclisma considerado como o decisivo combate que instaurará um mundo transfigurado; uma desproporção máxima entre os fins visados e os meios disponíveis, traço que demarca o milenarismo e a luta política. (SIRONNEAU, 1985, p. 263).

Sobre o caso da "religião política stalinista”, por exemplo, o Partido tende a tornar-se o depositário exclusivo da suposta "verdade revolucionária”. De acordo com Sironneau, as consequências desse processo são: o partido como lugar do saber e do poder, o partido como expressão ideológica do proletariado (o "Partido como Salvador e Messias") e a sacralização do partido fundada sobre o papel messiânico do mesmo, que é o depositário único de sentido do universo e da história. (SIRONNEAU, 1982, p. 414-415).

E, além dos atributos supramencionados, há necessariamente a articulação deles com uma estrutura enunciativa tradicionalista e, em se tratando do tradicionalismo, "todo tradicionalismo manipula as 'suas origens' em função das necessidades atuais" (FERNANDES, 1977, p. 68). Assim, nas experiências das religiões políticas - como do stalinismo, nazismo e o fascismo italiano - os partidos se colocam como os únicos legítimos conhecedores e enunciadores das origens, da tradição e das "verdades da tradição", aproximando assim, novamente, as religiões políticas ao conceito de fundamentalismo.

Até porque, "é possível afirmar que todos os fundamentalismos têm como característica comum o fato de se fundarem na tradição", e embora isso não queira dizer que todos os grupos tradicionalistas ou conservadores sejam fundamentalistas ${ }^{17}$, "a diferença dos fundamentalismos é que estes conferem a ela

\footnotetext{
${ }^{17}$ Até porque, todos os grupos religiosos e políticos recorrem, de algum modo, à tradição como narrativa de fundamento.
} 
um caráter absoluto, de algo revelado ou puro, mais próximo da experiência originária de seu grupo religioso”. (BALEEIRO, 2013, p. 33).

Sobre as dificuldades que os fundamentalismos possuem em se relacionar com os "discursos" plurais, as religiões políticas afirmam a sua autoridade em todos os âmbitos da vida social, rejeitam a coexistência com outros movimentos políticos, e algumas também rejeitam a coexistência com as expressões religiosas tradicionais, bem como se colocam como únicos portadores da "verdade" da melhor organização social ${ }^{18}$.

Portanto, desse modo, há elementos consideráveis para que as religiões políticas possam ser pensadas como fundamentalistas e, com isso, concordar com o pesquisador Emílio Gentile, para quem a religião política "sacraliza um sistema político fundado sobre o monopólio irrevogável do poder, sobre o monismo ideológico, sobre a subordinação obrigatória e incondicional do indivíduo e da coletividade a suas leis: ela é, de fato, intolerante, autoritária, fundamentalista, e procura impregnar qualquer aspecto da vida individual e coletiva”. (GENTILE, 2005b, p. 16).

Afinal, considerando que as religiões políticas podem ser compreendidas articuladas às concepções do fundamentalismo, e com isso abrindo certo caminho para reflexões relacionadas ao(s) fundamentalismo(s), cabe levantar algumas questões para trabalhos posteriores, embora de alguma forma elas já tenham sido colocadas. São elas: também as religiões civis não correm os riscos de serem fundamentalistas, devido ao fato de exigirem certa consensualidade em torno dos valores da pátria? As dinâmicas das religiões públicas estão imunes aos

\footnotetext{
${ }^{18} \mathrm{O}(\mathrm{s})$ fundamentalismo(s) é/são um fenômeno moderno, como a Religião Política, e "que tem a ver com a reação religiosa ao mundo moderno secularizado..."(DUARTE, 2012, p. 8), em uma dinâmica de reação a modernidade, mas também de apropriação dela. (BALEEIRO, 2013, p. 8). Os fundamentalismos estão relacionados com as tensões nascidas após o surgimento da necessidade do reconhecimento da diversidade e da pluralidade de "falas" na esfera pública, após a efetivação da Democracia, do Estado laico, do reconhecimento e respeito às minorias, do conjunto jurídico-legal em defesa dos Direitos Humanos, da secularização, da suposta autonomia da razão, e dos questionamentos às tradições. Todos esses elementos são negados pelas experiências relacionadas ao conceito de Religião Política.
} 
fundamentalismos, ou podem colaborar para o surgimento de fundamentalismos ao existirem expressões/organizações religiosas que disputam com o Estado laico, ou se juntam aos partidos, para imporem a cidadãos não religiosos suas pautas?

\section{Conclusão}

Há certas críticas ao conceito de religião civil, sobretudo ao desenvolvido pelo autor Robert Bellah, que embora não apontem diretamente para os riscos das religiões civis serem fundamentalistas, problematizam o conceito e abrem a possibilidade de pensar os "perigos" das religiões civis.

Robert Fenn, por exemplo, critica a perspectiva em que Bellah observa os Estados Unidos como um todo cultural. (GARCIA, 2005). O pesquisador Robert Fenn, "pelo contrário, assumindo o legado weberiano, sustenta que as sociedades modernas se caracterizam pelo politeísmo e o conflito entre os valores". (IDEM, 2005). Segundo Robert Fenn, a religião civil "não é mais do que a ficção cultural das classes dominantes, que, decidindo falar em nome dos valores da sociedade, estão elaborando uma retórica para favorecer seus interesses particulares". (GARCIA, 2005, p. 201-202).

Casanova, por sua vez, critica o conceito desenvolvido por Bellah porque observa, entre outros problemas, o risco da "perda da autonomia da esfera política implicado nessa contração entre comunidade política e comunidade nacional (CASANOVA, 1994, p. 60)". Paula Montero menciona, no que lhe concerne, que o conceito de religião civil é demarcado pelo "repertório protestante“, e com isso "deixa de fora um grande contingente de universos não cristãos". Ademais, conforme ela indica ter sido observado por Cristi (2001, p. 66), Bellah ao "remeter o cívico à nação", supõe, que a nação seja uma "entidade homogênea, senão desprovida de conflitos sérios ou tensões, ao menos apta a neutralizá-los via a fé cívica”. (MONTERO, 2018).

Para Paula Montero, portanto, "menos do que um instrumento analítico para pensar os processos de produção e articulação das diferenças em sociedades 
plurais, o conceito fica parcialmente reduzido a uma ideologia política da nação mobilizada como função legitimadora do Estado19". (MONTERO, 2018). Assim, talvez por razões diferentes das religiões políticas, também podem ser grandes os riscos de uma religião civil fundamentalista. E, como a religião civil pode ser compreendida como uma espécie, entre outras, de religião pública, cabe, não só, mas também por isso, a reflexão sobre as (im)possibilidades das religiões públicas serem fundamentalistas.

A respeito da relação entre fundamentalismo e religiões públicas, foi o pesquisador Joanildo Burity quem assinalou a possibilidade da reflexão articulada entre esses dois conceitos, em artigo (2018) que ele coloca a pergunta: "religião pública e a conjuntura do golpe: uma onda de fundamentalismos?”.

Burity relaciona as religiões públicas à mutação estrutural do status da religião no mundo contemporâneo, e observa que não existe um único modelo de religião pública, de tal modo que, segundo ele, “'fundamentalismo' deve ser claramente especificado se quisermos aplicar o termo como conceito, como categoria descritiva e até como bordão acusatório para caracterizar a religião pública nessa conjuntura”. (2018, p. 51).

Para Burity, se a religião pública implica também que o discurso religioso ao ser articulado publicamente precisa, de alguma forma, "prestar contas em público", ele compreende que a religião pública permite "afirmar a relacionalidade da religião no espaço público", e que, para o caso do Brasil, não é a "religião pública em si que realiza a hipotética virada fundamentalista na conjuntura brasileira", pois, para ele, a despeito da onda de conservadorismo atualmente existente, a utilização da justaposição golpismo, conservadorismo, fascismo, fundamentalismo, inflacionaria cada um dos termos e fragilizaria o que "poderiam ser anteparos preciosos no nível do associativismo civil, das religiões organizadas, dos partidos e

\footnotetext{
${ }^{19}$ A respeito especificamente de Bellah o pesquisador Bruno Reinhardt faz uma crítica a Bellah no que diz respeito as suas fontes de reflexão, ele observa que “(...) a religião civil opera como uma gramática, cuja finalidade última seria instituir e delimitar o campo das práticas e enunciações autorizadas. Esse aspecto é subvalorizado pela abordagem de Bellah, excessivamente focada em eventos cerimônias e, portanto, fortemente oficial e mesmo funcionalmente articulada ao problema da ordem ..." (REINHARDT, 2011, p. 19).
} 
da própria institucionalidade à generalização das formas regressivas de ocupação do espaço público que a cada dia se tornam mais desenvoltas em sua retórica e suas iniciativas de 'reformas"'. (BURITY, 2018, p. 62). Obviamente que essa é a compreensão de Burity sobre uma possibilidade e sobre uma dinâmica específica a experiência brasileira contemporânea -, e que a reflexão, como todas, entre as relações religião pública e fundamentalismo segue em aberto.

Por fim, em que pese as importantes pesquisas e discussões que podem se desenvolver a partir das possibilidades acima levantadas, tanto aquela sobre a articulação religião civil e fundamentalismo, quanto a relacionada à dinâmica das religiões públicas e o "fantasma", no mínimo rotulatório, do fundamentalismo que pode nascer delas, este artigo procurou apenas, primeiramente, distinguir o conceito de religião política, dos conceitos de religião civil e religião pública, e, depois, buscou indicar elementos que permitam possíveis articulações entre o conceito de religião política, e talvez as experiências representadas por ele, e certa definição de fundamentalismo.

\section{REFERÊNCIAS}

ARON, Raymond. L'avenir des religions séculières. Commentaire, Paris, n. 8, p. 28-29, 1985 .

BALEEIRO, Cleber. A. A dinâmica dos fundamentalismos: modernidade e tradição. In: SOUZA, Sandra Duarte de (org.). Fundamentalismos religiosos contemporâneos. São Paulo: Fonte Editorial, 2013. cap. 2, p. 15-44.

BARBOZA FILHO, Rubem. As linguagens da democracia. Revista Brasileira de Ciências Sociais, São Paulo, v. 23, n. 67, p. 15-37, jun. 2008.

BÈJAR, Helena. Una epoca de frio moral: la sociologia comunitarista de Robert N. Bellah. Reis, Madrid, v. 74, n. 96, p. 77-114, 1996. Disponível em: https://dialnet.unirioja.es/servlet/articulo?codigo=760552. Acesso em: 29 jul. 2020.

BELLAH. Robert N. A nova consciência religiosa e a crise da modernidade. Religião e Sociedade, Rio de Janeiro, v. 2, n. 13, p. 18-37, 1986.

BELLAH. Robert N. Comunitarismo ou liberalismo? Brasil e Estados Unidos em debate. In: SOUZA, Jessé de (org.). O malandro e o protestante: a tese weberiana e a singularidade cultural brasileira. Brasília: Editora Universidade de Brasília, 1999. cap. 12, p. 295-315. 
BELLAH. Robert N., Terrenoire Gwen. La religion civile en Amérique (Civil religion in America). Archives des sciences sociales des religions, Aubervilliers , n. 35, p. 7-22, 1973.

BIDUSSA, David. A religião da política em Israel. Revista de Estudos Avançados, São Paulo, v. 22, n. 62, p. 95-118, 2008.

BURITY, Joanildo. A onda conservadora na política brasileira traz o fundamentalismo ao poder? In: TONIOL, R; ALMEIDA, R. Conservadorismos, fascismos e fundamentalismos: análises conjunturais. Campinas: Editora da Unicamp, 2018.

CAMURÇA, Marcelo. Liturgias políticas e simbolismo no poder. In: BAPTISTA, Paulo Agostinho Nogueira; PASSOS, Mauro; SILVA, Wellington Teodoro da (org.). O sagrado e o urbano: diversidades, manifestações e análises. São Paulo: Paulinas, 2008. p. 7-286.

CAMURÇA, Marcelo. O debate conceitual sobre as religiões "cívica”, "civil” e "pública” proposto por Paula Montero e uma remissão para o caso do Brasil a partir de reflexões anteriores da autora. Debates do NER, Porto Alegre, v. 1, p. 42-57, 2018.

CASANOVA, José. From modernization to secularization to globalization: an autobiographical self-reflection. Chicago, 2011. Disponível em:

https://berkleycenter.georgetown.edu/publications/from-modernization-tosecularizationto-globalization-an-autobiographical-self-reflection. Acesso em: 29 jul. 2020.

CASANOVA, José. Public religions in the modern world. Chicago: The University of Chicago Press, 1994.

CASANOVA, José. Public religions revisited. Berlin: Heinrich-Böll Foundation; UNRISD, 2009.

CASANOVA, José. Religion, politics, and gender equality: public religions revisited. Chicago: 2009. Disponível em:

https://berkleycenter.georgetown.edu/publications/religionpolitics-and-gender-equalitypublic-religions-revisited. Acesso em: 16 jun. 2018.

CATROGA, Fernando. A religião civil do Estado-Nação: os casos dos EUA e da França. Coimbra: Revista de História das Idéias, Coimbra, v. 26, p. 503-581, 2005.

CATROGA, Fernando. Entre deuses e césares: secularização, laicidade e religião civil, uma perspectiva histórica. Coimbra: 2006.

DREHER, Martin N. Para entender o fundamentalismo. São Leopoldo: Unisinos, 2002.

GARCIA, José Antonio Santiago. Secularización y nacionalismo: un análisis comparado de los nacionalismos vasco y quebequense. 2005. Tese (Doutorado em Sociologia) - Universidad Complutense de Madrid, Madrid, 2005. 
GEERING, Lioyd. Fundamentalismo: desafio ao mundo secular. São Paulo: Fonte Editorial, 2009.

GENTILE, Emilio. Les religions de la politique: entre démocraties et totalitarismes. France: Éditions du Seuil, 2005b.

GENTILE, Emilio. Political religion: a concept and its critics - a critical survey.

Totalitarian Movements and Political Religions, Keele, v. 6, n. 1, p. 19-32, June 2005a.

GUIGOU, Nicolás. A nação laica: religião civil e mito-práxis no Uruguai. 2000.

Dissertação (Mestrado em Antropologia Social) - Universidade Federal do Rio Grande do Sul, Porto Alegre, 2000.

HERVIEU-LÉGER, Danièle. Representam os surtos emocionais contemporâneos o fim da secularização ou o fim da religião? Religião e Sociedade, Rio de Janeiro, v. 18, n. 1, p. 31-47, 1997.

HOBSBAWN, Eric; RANGER, Terence (org.) A invenção das tradições. Rio de Janeiro: Paz e Terra, 1997.

HORACIO, Heiberle Hirsgberg. Enunciados da política cubana: da simbologia do poder à possibilidade de uma religião da política. 2013. Tese (Doutorado em Ciência da Religião) - Universidade Federal de Juiz de Fora, Juiz de Fora, 2013.

HORACIO, Heiberle Hirsgberg. Religião civil de Rousseau a Bellah e Catroga: para uma análise da trajetória do conceito. Juiz de Fora: Anais do II Seminário de PósGraduação em Ciências Sociais - UFJF, 2010.

KERTZER, David. The Power of Rites. Ritual, politics an power. New Haven: Yale University Press, 1988.

LAZAR, Marc. Communisme et religion. In: COURTOIS, Stéphane ; LAZAR, Marc ; TRIGANO, Shmuel (dir.). Rigueur et passion: mélanges offerts em hommage à Annie Kriegel. Paris: Cerf, 1994.

LEITE, Márcia Pereira. A cidadania como religião civil de Rousseau a Bellah. Vassouras: VIII Encontro Regional de História, 1998.

MATA, Sérgio da. Passado e presente da religião civil. Varia História, Belo Horizonte, n. 23, p. 180-204, jul. 2000.

MONTERO, P. Religião cívica, religião civil, religião pública: continuidade e descontinuidades. Debates do NER, Porto Alegre, v. 19, p. 15-33, 2018.

ORO, Ivo Pedro. O outro é o demônio: uma análise sociológica do fundamentalismo. São Paulo: Paulus, 1996. 
PANASIEWICZ, Roberlei. Fundamentalismos religiosos: história e presença no cristianismo. Anais da ABHR, 2018.

PIERUCCI, Antônio Flávio. Estado laico, fundamentalismo e a busca da verdade. In: BATISTA, Carla; MAIA, Sonia (org.). Estado laico e liberdades democráticas. Recife: Articulação de Mulheres Brasileiras: Rede Nacional Feminista de Saúde: SOS Corpo: Instituto Feminista para a Democracia, 2006. p. 5-7.

PIERUCCI, Antônio Flávio. Fundamentalismo e integrismo: os nomes e as coisas. Revista USP, São Paulo, n. 13, p. 144-156, 1992.

PIERUCCI, Antônio Flávio. O desencantamento do mundo: todos os passos do conceito em Max Weber. São Paulo: Editora 34, 2003.

PIETTE, A. La religiosité et la sacralité dans le monde contemporain. In: RIVIÈRE, C.; PIETTE, A. (ed.). Nouvelles idoles, nouveaux cultes. Paris: Édtions L'Harmattan, 1990. p. 203-241.

PIETTE, A. Les religiosités séculières. Paris: Universitaires de France, 1993.

PORTIER, Philipe. Democracia e religião no pensamento de Habermas. Numen: revista de pesquisa e estudo de religião, Juiz de Fora, v. 16, n. 1, p. 611-622, 2013.

REINHARDT, Bruno. Reiterando o pacto: história, teologias políticas cristãs e a religião civil americana em uma era de multiculturalismo e império. Religião e Sociedade, Rio de Janeiro, v. 31, n. 2, p. 29-54, 2011.

RIVIÈRE, Claude. As liturgias políticas. Rio de Janeiro: Imago Editora Limitada, 1988.

RIVIÈRE, Claude. Le politique sacralisé. In: RIVIÈRE, C.; PIETTE, A. (ed.). Nouvelles idoles, nouveaux cultes. Paris: Édtions L’Harmattan, 1990. p. 29-47.

ROUSSEAU, Jean-Jacques. Do contrato social ou princípios do direito político. Tradução de Lourdes Santos Machado. São Paulo: Abril Cultural, 1973.

SIRONNEAU, Jean-Pierre. Quando a Sociologia encontra o imaginário. Iris, Recife, n. 2, p. 61-79, 1986.

SIRONNEAU, Jean-Pierre. Retorno do mito e imaginário sócio-político e organizacional. Revista da Faculdade de Educação, São Paulo, v. 11, n.1-2, p. 243-273, 1985.

SIRONNEAU, Jean-Pierre. Sécularisation et religions politiques. Paris: La Haye, 1982.

SOUZA, Jessé de (org.). O malandro e o protestante: a tese weberiana e a singularidade cultural brasileira. Brasília: Editora Universidade de Brasília, 1999. 
SOUZA, Sandra Duarte de (org.). Fundamentalismos religiosos contemporâneos. São Paulo: Fonte Editorial, 2013.

TOCQUEVILle, Alexis de. A democracia na América. São Paulo: Abril Cultural, 1985. (Coleção Os Pensadores).

VOEGELIN, Eric. As religiões políticas. Lisboa: Vega, 2002. 